Ioana Bot

Faculty of Letters, Babeş-Bolyai University

Cluj-Napoca, Romania

ioanaboth@gmail.com

\title{
REMEMBERING ROMANIAN COMMUNIST TIMES. NEW INSIGHTS ON THE BANALITY OF EVIL
}

\section{Recommended Citation:}

Bot, Ioana. "Remembering Romanian Communist Times. New Insights on the Banality of Evil”. Metacritic Journal for Comparative Studies and Theory 3.2 (2017): https://doi.org/10.24193/mjcst.2017.4.05

\begin{abstract}
Analysing two recent books in which prominent Romanian writers (Ana Blandiana and Gabriel Liiceanu) recount their lives during communism, we intend to reflect on how literary memoirs (written in very different forms) deal with the (recent) communist past and its troublesome heritage - not only for Romanian culture in general, but also for surviving individuals. Both authors under discussion attempt to come to terms with an evil they confronted daily in their regular lives; the questions they pose focus not only on "how that was possible", or "how evil could be lived through on a daily basis", but also on "how those stories are to be told" nowadays, to a reader growing more and more estranged from that past, and how those personal lives can get a more general, historical, meaning, through literature.
\end{abstract}

Keywords: communism, literary memoirs, everyday life, banality of evil, rhetoric of ethic, Ana Blandiana, Gabriel Liiceanu

Dacă, în timpul comunismului românesc, literatura a fost un substitut pentru discursul (interzis) al ideologiilor alternative (faţă de gândirea unică a Partidului), este evident că - după mai bine de douăzeci de ani de la căderea comunismului literatura (înțeleasă, în primul rând, ca o „Kunst durch Sprache”, ca o „artă a cuvântului”, adică, în descendență romantică, de fapt, și abia în al doilea rând ca „ficţiune”) continuă să exprime, în moduri oblice și alegorice din cele mai diverse, adevărurile care - deși nu mai sunt interzise - continuă să fie incomode. Dificil de 
rostit direct. Reluând o metaforă de succes, pe care poetul disident Mircea Dinescu o lansase în anii ' 80 ai secolului trecut (şi care îl costase, atunci, libertatea), vom spune că, vreme de două decenii după căderea comunismului, literatura română a continuat „să scrie pe dedesubt” despre comunismul abia încheiat, despre ororile lui enorme, ca și despre uriașele lui zone de gri: colaboraționisme, delațiuni, nostalgii, sovietofilii, oportunismele vieții de toate zilele. Cantitativ, ficțiunile despre comunismul românesc depăşesc studiile consacrate perioadei respective. În unele cazuri, chiar mărturiile supraviețuitorilor ororii sunt scrise recurgând la forme discursive ficționale: Madeleine Cancicov scrie un roman oniric-poetic, Temnița marionetelor (publicat în 1990), Lena Constante îşi rememorează, în anii '80, perioada de detenție (în care îi fusese interzis să posede măcar un creion!), sub forma unui jurnal cu datări zilnice, a căror precizie contribuie la efectul ficțional de autenticitate a mărturisirii (este vorba despre volumele Evadarea tăcută şi Evadarea imposibilă). Și exemplele pot continua. Recursul la ficțiune semnalează, în sine, o dificultate a raportării directe la trecutul recent - pentru că este un recurs îndeplinit cu mijloacele oblicității: figuri, retorică, discurs. $O$ artă a cuvântului vine să medieze ceea ce nu se poate spune direct: oroarea enormă, dar și răul cotidian, abjecția în formele sale deopotrivă majore şi minore.

Preocupată să discute valoarea istorică, recuperatorie, a „mărturisirii adevărului”, din această literatură, critica literară a fost mult mai puțin dispusă să reflecteze asupra semnificației întregului evantai de modalități prin care trecutul comunist, trăit „la prima mână”, era recuperat, în scrierile celor care îl trăiseră, prin intermediul ficțiunilor, adică „la mâna a doua”. Dacă, în perioada comunistă, literatura funcţionase ca un substitut (figurat, esopic etc.) al scrierilor istorice sau politice, pentru că ea putea spune adevărurile „pe dedesubt”, încețoşând criteriile axiologice, cu același gest, primele decenii postcomuniste au văzut cum ceața respectivă continua să persiste după ce interdicțiile politice dispăruseră.

După căderea dictaturii lui Ceaușescu, una dintre obsesiile intelectualilor români a fost recuperarea trecutului. De aici a izvorât o adevărată „foame” de povești de viață, „biografii mai mult sau mai puțin exemplare, foamea de destine - ratate sau împlinite - situate în centrul, la periferia sau printre pliurile tainice ale istoriei. După atâta dezumanizare şi alterare a „sufletului național”, setea de autenticitate pilduitoare, formativă, era cât se poate de firească”, nota Dan C. Mihăilescu (Mihăilescu 10-11). Foarte repede, a devenit evident, însă, că aveam de-a face cu o 
istorie „cu înlocuitori, firește” (12). Însă acolo unde Dan C. Mihăilescu sancționa, ironic, în cronicile sale din anii '9o, „eterna fobie a românului faţă de factologie și exactitate" (12), și ne încuraja să citim recursul la literatura subiectivă (sau, am spune noi, „ficțională”) despre comunism ca pe o „Halima [care] ne amână iluminarea pentru mileniul următor" (12), suntem tot mai tentaţi să vedem o dificultate de a ne apropia direct de memoria comunismului: direct, adică prin intermediul documentelor, al mărturiilor, „direct”, adică nu „oblic”.

Şi apoi a venit, ca să reluăm cuvintele lui Dan C. Mihăilescu (unul din cei mai rafinați cronicari ai recuperării adevărului despre comunismul românesc prin literatură), „mileniul următor”. Imperceptibil, la început, tot mai decis în ultimii zece ani, peisajul literar românesc al scrierilor „despre comunism” a început să se schimbe. Istoria literară va trebui să decidă, peste mulți ani și având pe-atunci posibilitățile unei sinteze retrospective, de la distanță, dacă modificarea aceasta este datorată în primul rând atingerii unei mase critice a respectivelor „adevăruri despre comunism" sau dacă esențialul care a contat în balanță s-a datorat unei modificări de mentalitate, coroborată cu multe alte elemente contextuale, destul de difuze. Acestea din urmă ne sunt, nouă, astăzi, mai perceptibile și ele privesc, de pildă, legiferarea și instituționalizarea accesului la dosarele Securității, posibilitatea crescută de a documenta și de a descoperi, din alte perspective decât aceea a literaturii personale, Istoria perioadei vizate. Ca un contrarelief față de literatura personală, subiectivă, care restituie foarte adesea o retragere în intimitate a creatorului din fața presiunii Puterii (comuniste), au fost publicate (și primite cu un apreciabil succes de public), câteva cărți bazate pe dosarele de supraveghere ale „rezistenților”, precum Clara Mareș, Zidul de sticlă. Ion D. Sîrbu în arhivele Securităţii (Curtea Veche Publishing, București, 2011), Jan Wilem Bos, Suspect. Dosarul meu de la Securitate (București, Ed. Trei, 2011), Coen Storck, Dosarul de Securitate al unui ambasador (București, Humanitas, 2013) etc. Restituirea publică a acestui alt volet al „banalităţii răului” determină apariția unor prime sinteze istorice, cum este cartea citată anterior, a Clarei Mareș (exemplară pentru noul câmp de cercetare) sau volumul Ioanei Diaconescu, Scrïtori în arhiva C.N.S.A.S. Intelectuali urmăriți informativ, arestați, condamnați, uciși în detenție 1946-1989 (București, Fundația Academia Civică, 2012).

Lor li se adaugă, în anii din urmă, un alt element care pare să inducă autorilor interesaţi de subiectul „adevărului despre comunismul românesc” o anume urgență - 
este vorba despre o nouă voce, care e tot mai audibilă pe scena intelectuală românească (îndeosebi, datorită mass-mediei şi noilor medii de comunicare), nu o dată fiind încurajată diabolic de bătrânii nostalgici ai dictaturii proletariatului. Este vocea unei tinere generații care (fără să fi trăit comunismul românesc), înțelege să își manifeste perspectivele critice asupra capitalismului actual inclusiv printr-un discurs ideologic de stânga, o stângă pe care, însă, grăbit şi greșit, o echivalează cu respectiva perioadă din istoria României. Noua stângă românească (inocentă sau nu în perpetuarea acestei confuzii, ceea ce este o altă discuție) proiectează asupra dictaturii comuniste o privire retrospectivă idilică (şi, de fapt, ficționalizantă); îndeobşte, ea se bucură de un succes la public care determină un anume sentiment al urgenței în spiritele ce realizează nu doar cauzele confuziei, ci și posibilele ei consecințe nefaste, pentru viitor. Se vor scrie, sunt sigură, studii interesante despre „locurile” în care aceste voci se rostesc; deocamdată - o fac cel mai adesea în pagini de reviste („Cultura” a fost, poate, cea mai importantă și cea mai vizibilă, mult timp) sau pe internet (de ex. Critic atac - www.criticatac.ro, care se autointitulează „platformă socială de stânga" în chip foarte generos, dar unde pozițiile unui Vasile Ernu sau Mihai Iovănel au adesea accente și poziții nostalgice). „Luarea cuvântului” este, o demonstra deja studiind la cald mișcările franceze ale anului 1968, Michel de Certeau, o luare a puterii, o afirmație de putere (De Certeau, 1994). Unele din cele mai importante voci ale criticii literare românești tinere (foarte prezente în mediile virtuale, de asemenea), ca Paul Cernat sau Alex Matei, îmbrățișează, cu o pasiune personală semnificativă, perspective revizioniste asupra comunismului românesc (aşa, de pildă, publicistica lor din ultimii 10 ani sau recentul volum pe care îl semnează împreună, 25 de ani după. Alternative şi provocări, Bucureşti, Adenium, 2015). În acest context, mulţi dintre autorii unor reconstituiri ale comunismului românesc, din ultimii aproximativ zece ani, mărturisesc a-și fi scris textele sub presiunea acestei urgențe, superior-pedagogice: pentru ca tinerele generații să învețe despre trecut, trecutul trebuie documentat, adus sub ochii lor ș.a.m.d.

Dar şi raportarea la trecut pare a se complica, tot mai mult. Pe de o parte, spuneam, e vorba de accesul documentat/documentabil la adevărurile dosarelor de urmărire, ale supravegherii continue, la adevărurile cotidianului violat de o privire rea. Pe de altă parte, asistăm la un nou recurs la scrierile nonfictive ca formă de restituire a trecutului recent. Este vorba despre publicaţii divulgative cu teme istorice care fuseseră dificil dacă nu imposibil de tratat în perioada comunistă (pe modelul 
editorial de succes lansat de istorici precum Lucian Boia sau de ziariști ca Tatiana Niculescu), despre antologii „mărturisitoare”, dar strict nonficționale (ca, de pildă, cartea realizată de Ioana Pârvulescu, Și eu am trăit în comunism, apărută în 2016), despre cărți construite pe baza dosarelor personale de urmărire de către Securitate, despre cărți de interviuri în care „supraviețuitorii” își amintesc (de obicei, către un reporter tânăr sau „mimând” tinerețea și necunoașterea Epocii de Aur) cum a fost. În diverse forme, ele sunt eseuri asupra banalităţii răului, inspirate de cotidianul comunist mai degrabă decât de momentele unei rezistențe eroice. Ele expun, povestesc și explică numeroase practici de locuire a cotidianului (același pe care Securitatea îl viola prin intervențiile sale) care caută să impună o normalitate (etică, existențială) lumii subiectului. Este o schimbare importantă a mizei „amintirilor din comunism”, în raport cu noul lor public cititor. Acesta din urmă nu mai e conceput ca fiind format din congeneri care, odată eliberați de dictatură, să dorească să îşi reconstituie Istoria și istoriile (personale) sau să recupereze adevăruri interzise. Ci este un public, majoritar, decisiv, format din cei care nu au cunoscut direct comunismul: „străini” (în sens la fel de bine literal sau figurat vorbind), neîncrezători, neonostalgici, vulnerabili în fața revenirilor unor ideologii malefice sunt cei ce alcătuiesc tinerele generații de astăzi. Lor li se adresează, cel mai adesea explicit, noile scrieri despre comunismul românesc - care, de asemenea, renunță la soluția ficțiunii și a metaforei, în favoarea restituirii documentare, în încercarea de a explica banalitatea răului trecut, cotidianitatea ororii, noneroismul existenței „dinainte vreme” (aceeași vreme în care nostalgicii își înrădăcinează la rândul lor discursurile encomiastice), ca și ubicuitatea supravegherii manipulatoare (ilustrare mai mult ca perfectă a teoriilor foucaldiene din A supraveghea şi a pedepsi).

Pentru ilustrarea acestor noi forme de recuperare a trecutului (deopotrivă dorind să ofere documentele, să le contextualizeze și să le explice, deopotrivă referindu-se la răul cotidian al comunismului, deopotrivă alegând poziționări noneroice), am ales două cărți de mare succes la apariție, publicate în același an, 2013: două formule diferite de a reconstitui practici personale, suscitate, însă, ambele, de acelaşi sentiment al imperativului recuperatoriu şi de adresabilitatea către un cititor „străin” de cele întâmplate cu mai bine de două decenii în urmă. Fiecare din ele caută să numească, să explice, să reconstituie un „innomabil”. Nu o dată, în retorica lor, răzbate un sentiment de frică abia disimulat, frica de uitare și pe cale de consecință - frica de posibilitatea repetării ororii. În atitudinea acestor 
intelectuali regăsim gesturile cu care Slavenka Drakulic decidea să scrie despre banalitatea ororii războaielor din fosta Iugoslavie, la câțiva ani după încetarea lor: „Atunci când, în 1995, la sfârşitul războiului, am văzut că în jur domneşte (...) aceeaşi manipulare a faptelor, mi s-a făcut frică” (Drakulic 23). Scrierile lor, așa cum spunea Vladimir Tismăneanu despre cartea Slavenkăi Drakulic, „ne ajută să înțelegem fenomenele de rinocerizare atât de specifice universului totalitar”, printr-o „asumare a trecutului în a cărei absență vechile instincte pot reveni, în forme probabil modificate, însă nu mai puțin periculoase" (Tismăneanu 8). Analizele de față fac parte dintr-un proiect mai amplu, consacrat analizei formelor de literaritate pe care le propun scrierile despre comunismul românesc, aparținând unei tipologii ample de intelectuali. M-am ocupat, cu alte ocazii, de memoriile concentraționare ale artistei plastice Lenei Constante, de dialogurile despre comunismul trăit și despre dezvrăjire ale profesorului universitar Paul Cornea. Intenționez să cresc numărul exemplelor; deocamdată, din rațiuni de spațiu tipografic, propun analiza a doar două dintre ele, apărute aproape simultan.

Voi vorbi, aşadar, despre două cărți apărute în 2013 - despre tentativele lor de a numi, explica şi înţelege, retrospectiv, oroarea cotidiană, existența (și rezistenţa) noneroică, fascinația și dezvrăjirea de ideologie, în comunismul românesc. Scrise în formule foarte diferite - o carte de amintiri și o restituire personală a propriului dosar de supraveghere de către Securitate - ele au, dincolo de această diferență aparentă, mult mai multe puncte în comun, prin modul de a se raporta la comunism ca experiență personală (și la dictatul Puterii, ca interlocutor şi făuritor al respectivei experiențe). Ceea ce mi se pare important de realizat, pentru istoricul literar care se ocupă de asemenea texte, este faptul că ele se cer analizate nu doar din perspectiva modurilor în care construiesc memoria, ci şi a modurilor în care construiesc un discurs al memoriei, adică - a noilor stiluri literare, ca tot atâtea practici punctuale, de restituire în limbaj a unei singularități existențiale extreme. Din acest punct de vedere, mă simt mai aproape de referințele (vechi) ale teoriilor lui Michel de Certeau. În studii precum La prise de parole (De Certeau, 1994) sau L'invention du quotidien (idem, 1990), acest autor pe nedrept ignorat de specialiștii români, atrage atenția asupra faptului că „locuitorii cotidianului”, la nivelul practicilor individuale (cu care răspund cerințelor și impozițiilor Puterii, de pildă), ascund o funcție creativă. Aceasta este, demonstrează De Certeau, extrem de importantă pentru a înțelege strategiile de supraviețuire personală. De Certeau numeşte atari practici „ruses” (fr. 
„şmecherii”) şi consideră că ele sunt principalele moduri de a se opune forțelor Puterii sau care aspiră la a avea Puterea. Întrucât asemenea moduri se manifestă în locurile comune ale cotidianului, consider că funcţionarea lor poate fi retrasată și la nivelul locurilor comune ale literarității, în scrierile personale care recuperează o memorie deopotrivă subiectivă și istorică.

Fiecare din ele începe cu o justificare la persoana întâi, adresată direct noului său cititor, interlocutorului văzut ca „străin” de tema abordată. Fiecare asumă poziționarea în contratimp și în replică la abordările literaturizante ale memoriei comunismului, care le-au precedat. Și, totodată, deși nici una nu este concepută ca proză diaristică, fiecare acordă un spațiu textual privilegiat poziționării eului (în tripla lui ipostază, de narator/mărturisitor/acuzator) şi modului cum putea trăi acesta în vremurile comuniste: practici de existență, stiluri de viață, moduri de a le spune. Diferența scripturală, aşadar, face casă bună cu o surprinzătoare convergență procedurală, atât în construcția obiectului (trecutul comunist), cât și în aceea a subiectului (care „spune povestea”).

\section{Revizitarea vieții de zi cu zi. Ana Blandiana, Fals tratat de manipulare}

Volumul Anei Blandiana este, înainte de toate, foarte diferit de scrierile aceleiași autoare, apărute anterior, având ca subiect comunismul românesc, și care recurseseră cu precădere la formula recuperării ororii prin intermediul unei ficțiuni metaforizante (de la prozele din Proiecte de trecut, până la romanul Sertarul cu aplauze). Acum, scriitoarea refuză catalogarea textului său printre „memoriile epocii”, postulând în deschidere un principiu fundamental interpretativ, iar nu ordonator al celor povestite mai departe:

Aceasta nu este o carte de memorii, chiar dacă uneori poate să lase această impresie. Ea nu este o încercare de a-mi povesti viața ci e o încercare de a o înțelege. De aceea, întâmplările nu urmează o ordine cronologică ci succesiunea logică a argumentației și nu sunt legate între ele decât prin asociații de idei și împletiri de obsesii. De fapt, încet-încet, prin selecție (o selecție care nu putea fi decât tendențioasă), obsesiile au fost reduse la una singură ce ar putea fi definită prin întrebarea: cât din ceea ce am trăit este un rezultat al voinței mele și cât se datorează influențelor, presiunilor și manipulărilor care s-au exercitat asupra mea? Și nu mă refer doar la faptul de a fi fost obligată să fac, mă refer și la faptul, infinit mai grav, de a fi fost uneori convinsă să fac. (Blandiana 5) 
Obiectul este, așadar, nu memoria ororii, ci „ceea ce am trăit”, expresie semnificativ-ambiguă, pentru că ea poate fi citită ca referindu-se și la „a fi trăit oroarea comunismului”, și la „a fi trăit” pur și simplu - cotidianul, viața prea singură, așa cum se putea. Sau așa cum ni se impunea. Ceea ce, ca obiect, este și provocator, prin antieroismul său voit, și nou, pentru că Ana Blandiana caută o reconstrucție a amintirilor despre comunism pe baza detaliilor mici generate de reflexele Puterii în plasma unei vieți personale.

Autoarea acceptă, desigur, deja în deschidere, că volumul poate fi citit și ca amintiri, dar insistă în a deplasa accentul semnificant al unei asemenea lecturi, pledând pentru interpretare, în defavoarea unei simple recuperări: „Desigur, este și o carte de amintiri doar în măsura în care amintirile pot deveni argumente” (7). Noneroică și nonficţională, Fals tratat de manipulare este, totodată, în mod programatic, interpretantă: „(...) nu am scris această carte pentru a transmite un adevăr pe care eu îl dețin, ci pentru a găsi un adevăr de care eu am nevoie. Sensul ei nu este să acopere ci să descopere ceva. Şi anume răspunsul meu la întrebările pe care singură mi le pun în legătură cu propria mea condiție și propria mea evoluție” (7). Un asemenea program întoarce vocea auctorială în teritoriile „mărturisirii”, venind însă dinspre o poetică diferită de aceea a „literaturii mărturisitoare” care a caracterizat cultura românească a primului deceniu postcomunist. Venind dinspre o scriitură în care Ana Blandiana își suspendă, conform unui ritm aproape „poetic”, narațiunile subiective, pentru a reflecta asupra funcţionării memoriei. Povestea vieții [ei] cotidiene în comunism alternează, contrapunctic, cu un discurs despre memorie. Iar memoria este, implicit, cea care dă substanță subiectului narator, deși autoarea se îndoiește de propria ei memorie:

Paradoxal pentru cineva care și-a închinat atâția ani reconstituirii memoriei colective, sunt o ființă cu o memorie personală mai mult sau mai puțin aproximativă și extrem de capricioasă. Pot să uit lucruri oricât de importante sau de grave, dacă nu m-au tulburat în clipa producerii lor, dar țin minte în cele mai mici nuanțe câte o replică sau câte o privire aproape neînsemnate, care au produs asupra mea un şoc, în funcție de persoanele cărora le aparțineau sau de fragilitatea psihică a momentului respectiv. Îmi amintesc și azi momentul când mi s-a spus că o poetă talentată - cu care nu mă cunoșteam prea bine și nici nu ne simpatizam în mod special, dar aveam impresia că ne respectăm, în interiorul acelorași valori - a exclamat aflând că sînt din nou 
interzisă: Așa îi trebuie dacă a vrut să fie celebră. Poate că n-am uitat episodul și pentru că mai târziu l-am găsit consemnat cu anumită mirare - dacă acolo putea fi vorba de sentimente - și în Cartea Albă a Securității, dar mai ales pentru că nu l-am înțeles, nici atunci și nici acum, și toată viața mea am fost dependentă de obsesia lucrurilor pe care n-am fost în stare să le înțeleg. (Blandiana 103)

Iar pentru Ana Blandiana, „a înțelege” înseamnă „a interpreta”.

Evocarea cotidianului comunist este, în întregime, impregnată de efortul (parcă, mereu eșuat) de a înțelege posibilitatea „banalităţii răului”. În această tentativă a sa, ca și în alte eseuri ale sale (centrate asupra Memorialului de la Sighet, de pildă), Ana Blandiana este, poate, scriitoarea care se apropie cel mai mult, în literatura română contemporană, de postura Slavenkăi Drakulic față de fosta Iugoslavie. Şi de timbrul scriptural al intervențiilor ei civice, când scrie pagini precum cele din $N$-ar face rău nici unei muşte, unde accentul nu e pus pe trecutul recuperat prin literatură, ci pe viitorul amenințător pe care o astfel de creație caută să îl împiedice a se naște: „(...) pe măsură ce realizezi că autorii crimelor de război pot fi oameni obișnuiți, te înspăimânți mai mult. Și e firesc, deoarece consecințele ar fi mult mai grave dacă ei ar fi monștri. Dacă oamenii obișnuiți au comis crime de război, înseamnă că oricare dintre noi poate fi criminal. (...) răul care izvorăște din gândirea obişnuită și este săvârşit de oamenii obişnuiți este norma, şi nu excepția” (Drakulic 174). O asemenea perspectivă, împărtășită și de Ana Blandiana, răspunde întrebării despre „Cum a fost posibil?” cu efortul de a identifica o rază de speranță, pentru că nu despre recuperarea trecutului ca monument este vorba, ci despre influențarea unui viitor pe care, Casandră ad-hoc, incomodă ca toate Casandrele, dintotdeauna, scriitoarea îl vede capabil de a cădea în aceleași capcane ale istoriei:

Când mă uit în trecut nu mă văd urcând dintr-un infern cu demoni și monștri ci dintr-o lume joasă, năclăită de umilințe, mizerii, dureri și complicități în care singura speranță era descoperirea sâmburelui, oricât de minuscul și de terfelit, de lumină din celălalt. O lumină care, dacă nu exista, trebuia inventată, oglindindu-ți propria flacără în aproapele mai nefericit decât tine. (Blandiana 18)

Falsul tratat de manipulare este, totodată, și o reflecţie amară, autoironică, despre imposibilitatea indivizilor de a se sustrage manipulării, adică - în subtext despre limitele libertății și ale rezistenței față de Putere: 
Important este să nu uităm că, pe cât ne vom gândi mai mult la toate astea, pe atât spectacolul pe care ni l-a prezentat își va fi atins scopul. La urma urmei, am știut dintotdeauna că o parte a puterii Securității era convingerea victimelor ei că este atotputernică. (Blandiana 86)

Ana Blandiana nu se erijează într-o învingătoare a ororii comunismului și nici nu asumă o postură eroică de-a lungul Falsului tratat. În loc să primească dimensiunile eroismului, gesturile sale de rezistență sunt explicate ca tot atâtea răspunsuri la diktatul Puterii - adică gesturi prin care individul, deși voind să își salveze libertatea, este manipulat de Putere, în chiar aceste încercări ale sale. Nu este cartea unei victorii, nici a unei poze eroice.

Ea rămâne, de altfel, o carte incomodă - și autoironică faţă de propria celebritate postcomunistă, ca „scriitor rezistent, luptând împotriva comunismului” în accentele ei discrete, aşa cum chiar sensul ei e construit din momentele (aparent) discrete ale cotidianului rememorat. Astfel, scriitoarea capabilă să electrizeze mulțimile după decembrie 1989 preferă oglinda unei întâmplări „de la țară” pentru a denunța pericolul simulacrelor pe care libertatea ni le dă atât de ușor, și care ne duc în ispită, în greșeală, în păcat. Ea acordă spații textuale privilegiate unor fabule umile, voit alese din registrul nonspectacularului, al unor discuții şi personaje minore în chiar „secundaritatea” cotidianului. Asemenea scene echilibrează tensiunea dramatică a momentelor de Istorie, dar deplasarea de accent asupra banalității celei mai perisabile este, totodată, un mod de a întări, în subsidiar, morala istorică. De aceea aş numi „fabule” asemenea anecdote (aparent benigne) care constelează textul cărții. Iată, de exemplu, scena unei discuții cu țărăncile de la Comana:

Voiau să știe, mi-a spus ea vorbind și în numele celorlalte (stăteau așezate în iarbă la capătul străzii după ce-și terminaseră toate treburile, într-un fel de odihnă înaintea somnului, în timp ce greierii începuseră vuietul care semăna în egală măsură cu roitul unei uzine şi cu un concert transmis la un radio cu volumul dat la maxim), voiau să ştie dacă, atunci când mă văd ele pe mine la televizor și vorbesc uitându-mă în ochii lor, le văd și eu pe ele. Și, cum pentru o clipă nu am înțeles întrebarea, mi-a detaliat-o explicându-mi că problema e dacă trebuie înainte să deschidă televizorul, să facă puțină ordine prin casă, să se îmbrace... În sfârșit, înțelesesem, dar până să izbucnesc 
în râs au izbucnit ele, intuindu-mi, înainte să formulez, răspunsul, ca şi cum întrebarea ar fi fost ea însăși o glumă, mai mult chiar o mică băşcălie, un fel de a mă ironiza și pe mine, și pe ele însele în același timp. Am stat alături de ele în iarbă până au început să apară stelele, râzând ca de o glumă bună de curiozitatea care - așa uimitoare cum era - nu mă îndoiam că fusese reală. Eram impresionată în fond aproape până la lacrimi, de atât de fireasca lor incapacitate de a înțelege simulacrul de comunicare pe care îl presupune televiziunea. Nu minunea că văd un chip pe ecran li se părea de neînțeles, ci faptul că acela deși văzut nu poate sau nu vrea să vadă, că vorbește fără să încerce să și asculte. Iată o problemă care nu ar fi putut să apară în nici o confruntare oricât de profundă de idei între intelectuali, dar care rezumă singurătatea lumii moderne, unde fiecare nu are decât interesul să fie ascultat, niciodată şi dorința să asculte. (Blandiana 38)

$\mathrm{Cu}$ alte cuvinte, dacă oroarea comunismului e căutată în cotidianul epocii unde Puterea manipula chiar tentativele de libertate interioară, exercițiul reflexiv asupra respectivei orori reușește să proiecteze, de la nivelul cel mai ,jos” al vieții de toate zilele, sensuri valide în general, în lumea modernă, mai presus de episoadele ei istorice, oribile sau nu, dar în orice caz - vremelnice.

De altfel, Ana Blandiana nu ezită să își ridice scrierea la generalizări despre „firea românului”, care depășesc limitele epocii comuniste. Pentru că, de fapt, „reconstituirea comunismului în viața cotidiană” e doar obiectul aparent al unei asemenea cărți, el disimulând (ca un „voluptuos joc cu imagini”) un efort de a interpreta și de a oferi o înțelegere - și o pedagogie - pentru ceva mai general și mai profund. Față de miza etică a căruia, Ana Blandiana se dovedește lipsită de cruțare:

Suntem, un popor lasămăsătelas. S-au bătut deasupra noastră munții în capete, au trecut peste noi toate popoarele migratoare și toți puternicii lumii, și noi i-am lăsat neîncercând să opunem rezistență, pentru că eram nu numai prea sceptici pentru a întrevedea luptei vreo șansă, ci și prea lucizi pentru a renunța la speranță de tot. Soluția, mai ales sudică, de salvare prin lasă-mă să te las, ca și înțelepciunea maramureșeană a lui Niciodată n-a fost să nu fie cumva, s-au născut din neputință și au generat neputință chiar dacă dețin și alte ingrediente: o simpatică și generală îngăduință, un paradoxal optimism după înfrângere, o bunătate cu înlocuitori, o slăbiciune de caracter metastazată... Suntem devorați de o corupție pornită de la blândul lasă-mă să te las, scăpată de sub orice control și devenită fiară de apocalipsă. Suntem terfeliți de nerușinarea și manipulați de minciuna unei clase politice alese 
contra cost și formată în parte din delincvenți care optează între închisoare și parlament pentru imunitatea celui din urmă. Umilințe fără hotar născute din firea noastră lasă-mă să te las, din lenea lipsei noastre de reacție și din mereu vinovata noastră speranță că totul se poate aranja. Suntem un popor lasă-mă să te las care, după ce a fost călcat în picioare decenii și secole lungi de alții, tot ce mai știe să facă este să se calce în picioare singur. (Blandiana 473)

Pentru a face asta, autoarea recurge la una din formele literare care îi poartă, în literatura română contemporană, „signatura stilistică”: este vorba despre pamfletul patriotic, amar, unde desenează efigii incomode ale poporului său. Incomode, firește, ca tot acest Fals tratat (...), mai interesant prin reflecţiile decât prin informațiile istorice pe care le conține. Ceea ce ne readuce, în reflecția asupra literaturii românești despre comunism, în teritorii cunoscute. La fel - în privința formulelor literare ale Anei Blandiana, în ale cărei scrieri, întotdeauna, istoria e povestită pentru a deschide calea reflecției, realul e mai bine reprezentat de metaforele lui, trezirea - de vis, etica - de fabulele aproape ludice.

\section{Supravegherea vieții de zi cu zi. Gabriel Liiceanu, Dragul meu turnător}

Ca și Ana Blandiana, Gabriel Liiceanu face parte din categoria intelectualilor incomozi pentru spiritul românesc. Este, de altfel, un rol pe care și l-a asumat cu „panaş”, atât înainte, cât și după căderea comunismului. În afară de scrieri de specialitate, el a semnat, în ultimele decenii, volume aparținând registrului autobiografic, într-o accepție largă, toate - cu o vădită predilecție pentru ridicarea experienței personale la nivelul general al unei reflecții etice. Stilist desăvârşit, el este unul dintre cei mai importanți creatori de retorică ai literaturii române din noul mileniu, chiar dacă pasiunile stârnite de pozițiile sale etice sunt de natură să distragă atenția cititorilor de la această componentă esențială a literaturii sale. În asemenea cărți recente (Ușa interzisă, Intâlnire cu un necunoscut), ca și în vechiul său Jurnal de la Păltiniş (devenit o carte-cult pentru ultimul deceniu al comunismului românesc, în pofida interdicţiilor Puterii), Gabriel Liiceanu recurge la un mixaj de formule discursive, mergând de la genul epistolar la eseul filozofic, într-o construcție foarte personală a unui subiect puternic, coerent (în chiar mijlocul amenințărilor resimțite la propria viață), cu accente narcisiace și cu retorici interogative ample. Stilul e reluat și în volumul din 2013, în care autorul publică ample fragmente din 
dosarul său de urmărire de către Securitatea comunistă, intercalate cu un discurs personal, adresat „turnătorului” său, într-o rescriere ironică a speciei „epistolei amoroase" (titlul dă, deja, cheia ironiei: Dragul meu turnător). Ca şi Ana Blandiana, și el simte nevoia de a lămuri de la primele rânduri dificultatea de a explica despre ce fel de carte este vorba:

Ca şi în cazul altor cărți pe care le-am scris, nu aş putea preciza cărui gen îi aparține acesta. Formal vorbind, avem de-a face cu o suită de epistole. Dar ce se ascunde în spatele acestor scrisori adresate unui personaj real? Un eseu? O povestire? Un document? Un fragment memorialistic? O ficțiune? Tot ce pot spune e că am scris paginile care urmează fără patimă şi fără ranchiună, din simpla nevoie de a înțelege geneza și fiziologia unei ticăloșii istorice. Dar poate, mai ales, din dorința de a ține trează uimirea în fața misterului răului care însoțește natura umană. (Liiceanu f.p.)

Dificultatea clasificării acestui tip de literatură se datorează nu doar formulei textuale neomogene, ci și mizelor sale - de ordin etic, iar nu restitutiv; aşa cum avertizează autorul însuși, ceea ce urmărește este reconstituirea unei experiențe comune (şi comunitare):

Interesul acestei cărți nu rezidă, aşadar, în «dosarul meu de urmărire informativă», ci, prin poarta pe care o deschide el către o experiență comună, în imaginea supravegherii totale obținute în comunism exclusiv în beneficiul puterii și întoarsă în mod potențial împotriva oricărui membru al societății. (Liiceanu 333)

Ceea ce narațiunea complexă din Dragul meu turnător propune este o explicare, dar și o asumare, a realității cotidiene a răului, adresată explicit celor care nu au cunoscut-o. Narativ vorbind, ea are structura unei coborâri în Infern, alternată contrapunctic cu o falsă scrisoare de dragoste - un experiment scriptural în sine. Cu începuturi înşelătoare, benigne:

Am să încep, aşadar, spunându-vă ce am simțit când, în noiembrie 2006, după ce făcusem o cerere la Consiliul Național pentru Studierea Arhivelor Securităţii (CNSAS), pe masa unei săli de la etajul III al acestei onorabile instituții, a aterizat „Dosarul de urmărire informativă numărul 907”, deschis pe data de 4 noiembrie 1971. Provenea din arhiva Direcției I («Direcția Generală de Informații Interne», menită să 
se ocupe de «munca informativă în rândul elementelor duşmănoase din interior») a Consiliului Securității Statului din cadrul Ministerului Afacerilor Interne al Republicii Socialiste România. Dosarul purta numele «Lungeanu», de fapt «Gelu Lungeanu». Acesta era numele meu de «obiectiv». Dosarul era alcătuit din cinci volume care totalizau câteva mii de pagini, marcate, la începutul fiecărui «material», cu antetul «strict secret». Un bazar uriaș al vieții mele, filmate din toate unghiurile posibile, alcătuit din rapoartele și notele ofițerilor, din «planuri de măsuri», din «note de analiză», din corespondența între Direcțiile Consiliului Securității, reprezentând tot atâtea forme de colaborare între Direcții privitoare la «obiectivul Lungeanu», din notele informatorilor («surselor»), din copii ale corespondenței mele şi ale corespondenței tuturor persoanelor din anturajul meu, din sute şi sute de pagini transcrise după înregistrările făcute cu microfoanele montate în casă şi telefonul pus sub ascultare, din note de filaj... (Liiceanu 43-44)

Într-o repoziţionare nu lipsită de accente diabolice, autorul își revizitează viața privată, parcurgându-și dosarul de supraveghere, prin ochii supraveghetorilor, care îi citeau toate scrisorile și îi transcriau toate conversațiile. Printre autorii denunțurilor se numără - alături de ofițerii de la Securitate, însărcinați cu urmărirea „obiectivului Lungeanu” - colegi și prieteni apropiați. Microfoane implantate în apartament completau tabloul: totul era la vedere, totul era transcris - dar orice transcriere este, inevitabil, o interpretare (pentru că este o naraţiune a celor înregistrate/văzute/auzite). Ilustrare involuntară a teoriilor lui Michel Foucault despre supravegherea perfectă din închisori, reconstituirea pe care dosarul personal de la Securitate i-o prilejuiește lui Liiceanu confirmă faptul că, în România comunistă, întreaga lume (nu doar - cum avertiza Foucault - şcolile, spitalele etc.) devenise o închisoare. Scriitorul încurajează însă o lectură care să transforme documentul reprezentat de dosarul de la Securitate într-o metaforă a actului în sine, o imagine a Răului ca intruziune de neoprit în banalul intimității:

Însă, înainte de adierea pericolului care se făcea simțită din maldărul acesta uriaș de hârtii, ceea ce te izbea, răsfoindu-le, era imaginea supravegherii. A unei supravegheri totale, mergând până la senzația că ți se cunoșteau nu numai gesturile și faptele toate, spuse și rostite între patru pereți, tot ceea ce aşternuseşi vreodată pe hârtie, întâlnirile noastre, dar și gândurile și stările cele mai intime. Ințelegeți? Tresăririle cele mai ascunse ale sufletului, dorurile, lehamitea, speranțele, spaimele, sfâșierile... Dar deopotrivă porcăriile pe care le spuneai sau pe care apucaseşi să le 
faci, pliurile conștiinței, partea ta de umbră rămasă în umbră chiar și pentru tine. Tipii aceia stătuseră în niște loji nevăzute, întreținute cu o uriaşă cheltuială, și mă priviseră defilând despuiat, ani și ani la rând, pe scena vieții. Mitul intimității în care crede orice om și în care orice om se învăluie, având nevoie să știe că există în el o parte care e numai a lui și în care poate oricând să se retragă, o parte ce reprezintă teritoriul inexpugnabil al ființei sale, blazonul singurătății și libertății sale, premisa sa de atom al speciei, de părticică indivizibilă a ei, se spulbera odată cu fiecare pagină a Dosarului. (Liiceanu 45-46)

Una din cele mai interesante axe pe care se construiește viziunea cărții privește - în descendența celor citate aici - ciocnirea dintre ego-ul puternic al subiectului și dezvăluirea impudică, violatoare (din dosar), a intimității care îl construiește, a chiar respectivului „teritoriu inexpugnabil al ființei sale”.

Maleficul supravegherii continue e perceptibil nu doar în impudoarea vederii, ci și în incapacitatea celui ce vede de a da un sens la ceea ce vede. Blocajul semantic al relatărilor despre „obiectivul Lungeanu” ar putea fi creator de efecte comice (prin defazajul pe care îl expune), dacă nu am presupune, generate de urmărirea continuă, consecințele diabolice/tragice ale acesteia. Supraveghetorii (zeloși) caută să noteze „totul”, dar este evident că nu înțeleg nimic din discuțiile celor urmăriți:

Dimineața stau fiecare în camera lui. La ora 15 s-au întâlnit la masă, după care revin în camere și dorm. La ora 19.20, Liiceanu Gabriel a venit la Pleşu Andrei și pleacă împreună la masă. La ora 20.15 toți trei vin la Liiceanu Gabriel unde au discuții. Acestea se referă la o lucrare de filozofie la care lucrează Noica C-tin. Se mai discută despre ce se poate vedea în Sibiu, mâncare, băuturi, femei. (Liiceanu 126)

Recitirea propriei vieți, astfel „văzute de supraveghetori”, poate suscita un rapel intertextual arhicunoscut cititorului român (pentru că versurile aparțin poetului național), dintr-un vechi adagiu romantic: „Şi când mă uit la viața-mi, îmi pare că ea cură/Încet repovestită de o străină gură./Ca și când n-ar fi viața-mi, ca și când n-aș fi fost.../Cine-i acel ce-mi spune povestea pe de rost/De-mi plec la el urechea și râd de câte-ascult,/Ca de dureri străine?...” (Mihai Eminescu, Melancolie). Dezvăluirea modului obscen în care subiectul fusese privit de „supraveghetori” se desfăşoară în paralel cu o acută înstrăinare a subiectului de sine însuși - privirea străină, care violase intimitatea fără să înțeleagă nimic din sensurile vieții astfel 
privite, reușește (diabolic) să opereze un „transfer de alienare” retroactiv, asupra eului:

Dar în ziua de 5 noiembrie 1971? Oare ce a făcut „Lulu” în acea zi, la ora 18.55? La ora 18.50, Lulu, având o plasă în mână a ieșit din casă, a mers pe diferite străzi, str. Labirint, și a intrat la magazinul alimentar cu autoservire din colț cu str. Traian, de unde a cumpărat un pachet de Dero, după care a ieșit și a mers pe str. Traian, cal. Călăraşi, și a intrat la centrul de pâine din stația Piața Traian, de unde a ieșit după 2 minute, având în mână plasa în care se mai găsea și 1⁄2 pâine albă, apoi a mers pe cal. Călărași și a intrat la magazinul Metalo-chimice de unde a cumpărat două cutii de decolorant, a ieșit și pe diferite străzi a mers la domiciliu, unde a intrat la ora 19.20. până la ora 21.30, când postul a fost ridicat, obiectivul nu a mai părăsit domiciliul. Filajul continuă. (Liiceanu 106)

Nu întâmplător, Gabriel Liiceanu recurge, în volum, la o lectură paralelă a unor fragmente din scrierile sale diaristice (teritorii, prin excelență, ale construcției subiectului ca deținător al sensului propriei lumi) cu fragmente din dosarul de supraveghere (teritoriu al lipsei de sens, al cioburilor incapabile să realizeze o imagine întreagă, dar și al deposedării subiectului de sine), pentru că - de fapt miza etică a cărții este oferită cititorului prin intermediul unor construcții stilistice (dintre care contrastul scriptural e una din cele mai eficiente) care să îl conducă, implicit, către adevărul autorului. Aceeași zi din viața autorului este notată și în celebrissimul său volum Jurnalul de la Păltiniş, și în dosarul de supraveghere. Cele două texte se află, sub aspectul „artei cuvântului”, la antipozi. Dar sensurile lor? Şi, mai puternic decât acestea, sensurile alăturării lor, în această carte? În Jurnalul de la Păltiniş, pentru data de 2 octombrie 1977, notația este următoarea:

Sunt din nou la Păltiniș cu Noica și, de astă dată, și cu Andrei. Același tren de 9.45, acelaşi Relu Cioran aducându-i lui Noica în gară la Sibiu bunda şi căciula, apoi trecerea cu autobuzul prin Rășinari către Păltiniș, cu aceleași lămuriri și ghidaje, adresate de astă dată lui Andrei - îmi amintesc că pe același drum, acum câteva luni, l-am invocat, întrebându-ne cum va arăta Germania - totul s-a repetat pentru a pregăti din timp reîntâlnirea cea bună cu un loc pe care încă de pe acum îl simt așezat definitiv în mine. (Liiceanu 116) 
Mai detaliată, și inutilă în profunzimea sa de detalii (ca un fragment de „literatură brută”, dacă conceptele „artei brute” ne-ar permite analogia), nota informativă transmisă de Serviciul F (U.M. o883), din Sibiu, sună astfel:

Activitatea obiectivului. La orele 15.50, NICU (nume conspirativ pentru Noica) a coborât din trenul accelerat 221 pe peronul gării Sibiu, împreună cu doi indivizi porecliți NAE și NOE (nume conspirative pentru Lüceanu și Pleșu), cu mai multe bagaje voluminoase și cu un rucsac. În timp ce mergeau spre ieșire, s-a întâlnit obiectivul cu un individ căruia i-am dat porecla NELU (nume conspirativ pentru Cioran) și împreună au mers discutând pe strada 9 Mai până în stația ETS pentru autobuzele de Păltiniş. În acest loc, NAE şi NOE au rămas cu bagajele, iar obiectivul NICU împreună cu legătura NELU au mers la cofetăria Albina şi au discutat amical timp de 30 de minute și au consumat prăjituri și suc. La orele 16.40 au ieșit din cofetărie și s-au deplasat la autobuz. S-au urcat cu toții și au continuat discuția până la orele 16.55 când s-au despărțit. NELU a coborât luându-și rămas bun și a fost luat în filaj pentru identificare, stabilindu-se că se numește CIORAN și domiciliază la Sibiu str. N. D. Cocea nr. 5. Obiectivul NICU împreună cu NAE şi NOE au continuat drumul spre staţiunea Păltiniş. La orele 18.30 au coborât și au mers la biroul de cazare, aici obiectivul NICU are reținută o cameră la vila 23. Au achitat sumele pentru 10 zile de cazare și masă după care s-au deplasat la vilă lăsând bagajele în clădirea telefoanelor şi a biroului de cazare. După 15 minute au venit la birou, legăturile NAE și NOE au fost nemulțumiți de starea camerelor din vila 23 și au plătit diferența pentru cazare la hotelul Cabana Turiștilor. Obiectivul a rămas în continuare la vila 23. Menționăm că legăturile NAE se numește /sic!/ PLEȘU GABRIEL, domiciliază la București, iar legătura NOE se numește LIICEANU GABRIEL domiciliat în București. Filajul a luat sfârşit. Șef Serviciu F, colonel Ioan Vecerdea. (Liiceanu 117-118)

Lectura contrapunctică a celor două moduri de configurare a subiectului (văzut de sine și puternic, respectiv văzut de voyeuriștii Securității, deci slab în fața lor) este, în primul rând, un procedeu cu miza pedagogică la vedere. Liiceanu îl practică în mod repetat pe parcursul cărții. Dar mi se pare semnificativ faptul că, fie și din asemenea alternări de fragmente, contrapunctice prin toate caracteristicile lor (dar referindu-se la unul și acelaşi moment din real), ceea ce i se transmite (educativ, explicativ) cititorului nu este doar axa etică a unei reflecții, ci și o implicită pledoarie pentru forța literaturii - de a media transmiterea respectivelor valori etice. 
Documentul „de dosar” întărește poziția privilegiată a literaturii ca modalitate de cunoaştere.

\section{Concluzii}

Ceea ce ne readuce în sfera discuțiilor cu care deschisesem paginile de față - și care priveau modurile recursului la Literatură (da, cu majusculă) ale scrierilor care caută, astăzi, să recupereze memoria comunismului românesc. Dacă nevoia de cunoaștere a adevărului fusese reflectată, în primele decenii de libertate, de o proliferare a literaturii de ficțiune (inclusiv a formelor ficţiunii puse în slujba scrierii documentare - precum falsele jurnale ale Lenei Constante, de exemplu), centrarea asupra documentelor de arhivă și a reconstituirii vieții cotidiene, non-eroice, din scrierile ultimului deceniu, nu modifică - cum s-a putut vedea în volumele analizate - poziția privilegiată a literaturii ca vehicul al adevărului astfel recuperat. Parafrazând un vechi adagiu, vom spune „La cititori noi, soluții (literare) vechi”. Ceea ce este, incontestabil, încurajator pentru literatură ca „artă a cuvântului”, respectiv ca formă de cunoaștere. Pentru că, dacă oroarea cotidianului și banalitatea răului par a fi dificil de povestit (dacă nu imposibil), formele literare sunt, din nou, cele care pot să o facă. Iar dacă ne temem că oroarea se poate repeta - din necunoaștere, din orbire, din răutate (toate, trăsături ale umanității, de neșters) - din nou, literatura poate să ne apere de un asemenea coșmar. 


\section{Referințe}

Blandiana, Ana. Fals tratat de manipulare. București: Humanitas, 2013.

Bos, Jan Wilem. Suspect. Dosarul meu de la Securitate. București: Ed. Trei, 2011.

Cancicov, Madeleine. Le cachot des marionettes. Paris: Ed. Critérion, 1990.

Constante, Lena. Evadarea imposibilă. București: Humanitas, 2013.

---. Evadarea tăcută. București: Humanitas, 2013.

Cornea, Paul. Ce a fost, Cum a fost, dialoguri cu Daniel Cristea-Enache. Iași: Polirom, 2013.

De Certeau, Michel. L’invention du quotidien. Paris: Gallimard, 1990.

---. La prise de parole. Paris: Seuil, 1994.

Diaconescu, Ioana. Scrïtori în arhiva C.N.S.A.S. Intelectuali urmăriți informativ, arestați, condamnați, uciși în detenție 1946 - 1989. București: Fundația Academia Civică, 2012.

Drakulic, Slavenka. N-ar face rău nici unei muşte, traducere de C. Pleșu. București: Curtea Veche Publishing, 2008.

Foucault, Michel. A supraveghea şi a pedepsi, traducere de B. Ghiu. Pitești: Paralela 45, 2005.

Liiceanu, Gabriel. Dragul meu turnător. București: Humanitas, 2013.

---. Intîlnire cu un necunoscut. București: Humanitas, 2010.

---. Jurnal de la Păltiniș. București: Humanitas, 1991 (I - 1983).

---. Uşa interzisă. București: Humanitas, 2002.

Mareș, Clara. Zidul de sticlă. Ion D. Sîrbu în arhivele Securitățiii. București: Curtea Veche Publishing, 2011.

Mihăilescu, Dan C. Literatura română în postceauşism, I. Memorialistica. Iași: Polirom, 2004.

Pârvulescu, Ioana. Și eu am trăit în comunism. București: Humanitas, 2016.

Storck, Coen. Dosarul de Securitate al unui ambasador. București: Humanitas, 2013.

Tismăneanu, Vladimir. "Prefață la Slavenka Drakulic”. N-ar face rău nici unei muște. București: Curtea Veche Publishing, 2008, pp. 7-12. 